\title{
Addressing the Knowledge Gaps in Agroecology and Identifying Guiding Principles for Transforming Conventional Agri-Food Systems
}

\author{
Angelina Sanderson Bellamy ${ }^{1,2, *}$ and Antonio A. R. Ioris ${ }^{2}$ \\ 1 Sustainable Places Research Institute, Cardiff University, Cardiff CF10 3BA, UK \\ 2 School of Geography and Planning, Cardiff University, Cardiff CF10 3XQ, UK; IorisA@cardiff.ac.uk \\ * Correspondence: BellamyA1@cardiff.ac.uk; Tel.: +44-7505-936341
}

Academic Editors: Manuel González de Molina and Gloria Guzman

Received: 12 January 2017; Accepted: 16 February 2017; Published: 23 February 2017

\begin{abstract}
Today's society faces many challenges when it comes to food production: producing food sustainably, producing enough of it, distributing food, consuming enough calories, consuming too many calories, consuming culturally-appropriate foods, and reducing the amount of food wasted. The distribution of power within the current mainstream agri-food system is dominated by multinational agri-businesses that control the flow of goods and wealth through the system. This hegemony has implemented a regime whose structures reinforce its control. A growing response to the current agri-food regime is the rise of agroecology, in both developed and developing country contexts. This is not a new phenomenon, but it has evolved over time from its Latin American origins. However, agroecology is not a monolithic block and represents many different perceptions of what it means to advance agroecology and ways in which it can help today's society tackle the crisis of the agri-food system. This paper addresses these sometimes discordant view points, as well as the gaps in our knowledge regarding agroecology in an effort to lay out some guiding principles for how we can move forward in transforming the current agri-food system to achieve sustainability and a more equitable distribution of power and resources.
\end{abstract}

Keywords: agroecology; agri-food system; political ecology; equity; power

\section{Introduction}

Today's agri-food system is in a state of crisis. The problems evolve in different scales and unfold in multiple directions. Researchers, policy-makers and NGOs grapple with dilemmas of providing affordable food for urban populations, combating public health problems of obesity and other dietary-related communicable diseases, decreasing dependence on food imports and slowing the rural exodus of the small-family farm. To add a sense of urgency to the crisis, there is a continuing dialogue on the need to increase global food production to feed a growing population in fair and sustainable ways. Soil degradation, water contamination, groundwater depletion, deforestation and land cover change, health effects of exposure to pesticides, biodiversity loss; all of these problems can be attributed, at least in part, to conventional food production practices associated and influenced by global and local market transactions. However, arguably, the distribution of power and wealth within the current agri-food system among large retailers and multinational corporations enables them to promote a system that works mainly for the few at the top. The growth of agroecology is in part a response to these disparities and aims to redress the ecological, social, economic and political imbalances in the current agri-food system.

Agroecology, for some, is a contested and confusing term, with some authors calling for "those who publish using this term (to) be explicit in their interpretation" [1] (p. 503); [2]. The multiple uses 
of the term are due to cultural, historical, geographic and epistemological reasons, and the definition and content of the term has evolved, as has the political and scientific agendas associated with the concept. While the cultural and historical circumstances differ widely, economic exclusion associated with the current conventional agri-food system, coupled with the need to increase food production and maintain consumption, has created a socio-ecological crisis, which can potentially catalyse a new movement aimed at reforming agri-food along agroecology lines.

This paper addresses the current trends in agroecological thinking, including an increasing shift towards political agroecology, in which several founding authors such as Gleissman $[3,4]$ and Altieri and Toledo [5] are articulating an action-oriented, transdisciplinary and explicitly political interpretation. Current contributions focus on debates that are moving agroecology into increasingly political spaces, using lenses including food sovereignty and food justice, wider and multiple ecological crises (food-water-energy-economic-climate) and considering what a transition to sustainable food production might look like. But while agroecology is moving further into political spaces, which seems to be the most interesting and creative repercussions of agroecological concerns, there is also movement into the mainstream, as agroecological practices are seen as a sustainable option for food production. Agroecology can be described as not only a set of technological and practical adjustments, but it is also a transnational social movement in which a simultaneous coherent and diversified body of collective action evolves in the global geographical setting through complex interactions between grassroots activity and centers of coordination. This movement must be navigated carefully, however, if it is not to be subsumed by the current agri-food hegemony due to the relatively easy appropriation of agroecological techniques (at the expense of the more critical and political dimensions).

Given this rise in a more wide-spread agroecological movement, there are several significant questions that arise with regards to how agroecology can move forward to tackle some of the more pressing challenges of the current global and mainstream agri-food system. On the ecological side, there still remains ongoing debate around the levels of productivity that can be achieved within agroecological systems (considering that these are ecosystems manipulated by anthropogenic modifications deeply rooted in the traditions of small-scale, family farming, in which plants, animals and microbial communities cohabit with agricultural uses and provide relevant ecosystem services). Challenges that straddle the social-ecological divide are the nature of and relationship between elements within the food system and how knowledge generated within agroecological systems can be made relevant for policy makers in order to secure food supply. We need to better understand the socio-economic and policy factors that hinder or enhance the development of agroecology. Finally, in considering the social aspects of agroecology, we also need to identify the trends and drivers encouraging the involvement of farmers, actors in the value chain, consumers, educators and policy makers in agroecological systems. There is also a need for greater analysis of the uses of agroecology discourses and ideas in different framings of and responses to food debates.

Agroecology needs also to make the most of its potential as a social movement that can help build social capital and shape a new social and economic order behind more sustainable and just food production and consumption systems. Promoting agroecological practices may not be sufficient to achieve long-term resilience, unless local and global food systems undergo a more structural transformation; food value chains are reoriented towards increased efficiency and re-localisation with increased communication between producers and consumers; and consumers make more thoughtful and healthy choices. The range of material and discursive activities that constitute agroecology interconnect different scales and, although these may be experienced at the local level, they reflect a politicised construction of scales (which means that scales are not fixed, but constantly interacting and mutually transforming each other). Consequently, the local elements of agroecology need to be analysed and considered in relation to other, higher scales of interaction.

Addressing these questions and challenges will contribute to understanding how to achieve transformations in the food system to promote a holistic and sustainable approach to food production based on local, place-based food interactions and connections with higher scales. We will examine 
both the social and ecological aspects of agroecology and explore the potential of agroecology to transform food production. In this paper, we highlight the major knowledge gaps in research and policy regarding the transformation of conventional agri-food systems. Going beyond the production side of the agri-food system, we will survey political (structural) changes [6]. We present a critical analysis of what is needed in agroecological research in order to transform conventional agri-food systems to achieve sustainability.

\section{Streams within the Agroecology Movement}

The current literature indicates the development of agroecology into two clear 'family groups' of concepts. The first is a narrow, technology-focused agroecology, associated with Western scientific epistemologies and methodologies, and analyses of food crises that tends to concentrate only on technological and procedural interventions [7]. The second is a broader and more radical agroecology. In addition to the ecological side of the production system, the approaches within this group encompass a participatory social movement towards autonomy and sustainability in food production, and a more overtly "political agroecology" [8] (p. 45), which considers food production as inherently political, draws attention to broader food production and consumption systems, and which foregrounds power and politics. Latin American agroecology, for instance, has its roots in social movements explicitly aimed at agrarian empowerment, which emerged as a response to economic exclusion produced by agricultural modernisation [2].

Into this first family group falls scientific agroecology, which has traditionally focused on ecological processes of food production at a plot or farm scale, rather than the wider social, cultural or political processes, considering them to contrast with scientific knowledge [9]. Scientific agroecology therefore tends to support technological and production-oriented initiatives. This excludes social, cultural and political issues, in particular the critique of agri-food systems from social sciences, from its analysis. However, the concept of a food system has allowed scientific agroecology to include social aspects [10]. This systems approach has recently been given greater prominence by authors, such as Francis et al. [11] (p. 100), who define agreocology as "the integrative study of the ecology of entire food systems, encompassing ecological, economic and social dimensions, or more simply the ecology of food systems". Further contributing to this widening of perspectives, Vandermeer and Perfecto [12] and Ernesto Mendez et al. [7] call for a transdisciplinary approach to agroecology, whereby different types of knowledge gained by multiple methods of inquiry, including knowledge generated by farmers, are brought to bear on solving problems. They advocate a research agenda based on a transdisciplinary and inclusive approach, which focuses on complex systems driven by actual food problems.

Practical agroecology, from the second family group, is seen as a systemic and holistic approach to the farm's ecosystem [5]. Core techniques and practices include: minimising and ideally omitting chemical and high energy use; making use of the properties of the whole farming system (i.e., recycling nutrients, building the soil organic matter, preserving agro-biodiversity and resources, etc.); focusing on diversity, rotations and polyculture to enhance beneficial interactions; using native seeds, plants and livestock; and using holistic techniques for fertilisers and pest control such as introducing natural predators of pests. Agroecological principles centralise farmer knowledge, which is often viewed as an inherently political means of challenging top-down food institutions and corporate interests [12-14]. They promote small-scale agriculture in which peasants are empowered, e.g., with secure land tenure, community seed banks and appropriate credit policies [5]. Agroecology emphasises independent experimentation rather than dependence on high-tech equipment from external suppliers with a high degree of dependency on support services [5]. Agroecology also emphasises collaborative and communal social practices, such as knowledge sharing. Knowledge sharing is seen as one of the most fundamental components of agroecology, with Alteri and Toledo [5] (p. 589) arguing that "human resource development is the cornerstone of any strategy aimed at increasing options for rural people and especially resource-poor farmers". Other concepts include low energy inputs [15], family and community work [16] and local markets [17]. 
In this context, agroecology is distinct from mainstream and industrial agriculture techniques, which rely on monocrops, high use of chemical fertilisers and pesticides, and commodified inputs such as patented seeds. Agroecology should also be distinguished from organic in that it emphasises a whole-system approach with minimal external inputs. For example, organic farming still relies on external inputs such as organic fertiliser, may still produce single or few varieties of crops or livestock, and may not necessarily prioritise other holistic principles like water conservation or use of renewable energy.

Practice-based agroecology can also be seen in more overtly social terms. Several of agroecology's significant proponents have consistently emphasised the transformative potential of agroecology as a practice-based social movement, primarily in Latin America [5,18]. Gonzalez de Molina [8] (p. 51) defines agroecology as "a disciplinary field responsible for designing and producing actions, institutions and regulations aimed at achieving agrarian sustainability". Altieri and Toledo view it as a "paradigm based on the revitalisation of small farms and social processes that value community involvement and empowerment" [5] (p. 589).

These definitions share a commitment to using alternative modes of food production to bring about broader changes for the better in social and ecological outcomes. Empowerment and participation, based on techniques and ideas pioneered by Robert Chambers [13,19], are viewed as central to bringing about positive change $[20,21]$. These approaches explicitly position practical agroecology as a social movement for change, and theorise it as a counter-movement to mainstream agri-food systems $[1,2,5,22]$, which leads to the next stream of agroecology.

Political agroecology, a more radical branch of the second family group, and explicitly labelled as such by Gonzalez de Molina [8] (p. 45), considers agriculture and food production as inherently political, and calls for concepts of agroecology which foreground power and politics. This approach is related to the sub-discipline of political ecology and draws attention to power relations such as class and gender which produce uneven access to natural resources and which produce ecological degradation (e.g., [23]). Political agroecology is concerned with broader food systems, especially the conventional agri-food system dominated by large corporations, market ideologies and governments.

Political agroecologists argue that social and economic relations shape access to food, and as such they centralise analysis of class and other power relations that shape access to natural resources. They often foreground capitalist and neoliberal food production relations, which reduce social and natural worlds to labour and commodities $[5,8,24,25]$. Its proponents predominantly focus on critiques of what they view as the dominant agri-food hegemony, such as the debate over 'food versus fuel' in relation to bioenergy [26]. However, there is an ideological split between reforming the current food production system, and those who want to radically change it, as well as several interpretations of how to bring about change to the food system.

Political agroecologists aim to increase farmers' control over aspects of food production through practice, thereby improving food sovereignty $[7,8]$. By giving voice to those that have traditionally been excluded, political agroecology seeks to improve access to resources and make research more suited to the livelihood needs of the poor. This advocates for the transformative and emancipatory involvement of small-scale farmers "as a necessary component to develop a more sustainable agriculture" [7] (p. 8).

There is significant crossover between these definitions and the transdisciplinary perspectives discussed above. Practical agroecology is often characterised as a social movement rooted in peasant's reactions to top-down food production systems such as the Green Revolution of the 1960s and 1970s. This is often characterised as a conflict between peasant agriculture and modern agri-business [2]. For example, Rosset et al. [14] (p. 162) argue that agroecological practices avoid reproducing the agri-business model thereby avoiding the reproduction of "the forces of exclusion and the destruction of nature, which define the larger conflict".

This co-evolution of science, practice and politics is emerging as an important current debate in how to define agroecology. Sevilla Guzman and Woodgate [22] (p. 32) argue that "attempts to define agroecology as an applied science without a social context, without problematizing capitalist 
relations of production or allying itself with agrarian social movements, will significantly limit its ability to contribute to more sustainable systems of food production, distribution and consumption". The whole system approach is also emphasised by Gliessman [4] (p. 1), who identifies agroecology as a field dedicated to "transforming food systems to sustainability". The expansion of agroecology to encompass complex issues including "resource depletion, environmental degradation, a narrowing of agro-biodiversity, continued world hunger and food insecurity, climate change and loss of farmers and farmland" [4] (p. 2) means that it is increasingly embracing a transdisciplinary approach, with Ernesto Mendez [7] (p. 3) calling for "multiple agroecologies" (also [12]).

However, as also pointed out by Gonzalez de Molina [8], these current attempts to redefine agroecology as inherently politically focused, transdisciplinary, and broadly concerned with 'food systems' need clarification (including processing, transformation, distribution and conservation of foods). First, the problem of how to define a 'food system', and related problems of how to draw its boundaries, and what causative factors to include, is important. These include improving agroecologists' theorising around scale; for example, there is a need for greater consideration of the nature of the relationship between farmers' actions and changes at a state or international level [8], and around the sorts of territorial and institutional arrangements that will bring about sustainability [27]. Second, Wezel et al. [1] (p. 40) note that agroecology can be a "vague, confusing and ineffective" term and thus strongly open to use by a variety of actors with potentially contradictory agendas-the question of who is using the term and why is under-analysed. For example, there is currently little empirical research on the various definitions of agroecology used by corporate, NGO and development actors. The vague and diffuse defining of agroecology makes the movement vulnerable to being incorporated by the current mainstream agri-food system, which can define and thereby limit agroecology in ways suitable to its own purposes.

More recently, some authors have associated the concept of a food system with the more political (although rather simplistic and structuralist) 'food regime' [28], which is defined as a "rule-governed structure of production and consumption of food on a world scale" [29] (pp. 30-31). Analysing a food regime encompasses political, economic and social analysis to understand the role of food production and consumption relations, particularly in the context of global capitalism [25]. According to many political agroecologists, the current food regime is characterised by "the unprecedented market power and profits of monopoly agri-food corporations, globalised animal protein chains, growing links between food and fuel economies, a 'supermarket revolution', liberalised global trade in food, increasingly concentrated land ownership, a shrinking natural resource base, and growing opposition from food movements worldwide" [25] (p. 111). The last authors identify actors within the corporate food regime as including agri-food corporations, which tend to be large transnational businesses operating as monopolies, institutions including the World Trade Organisation, which maintains the international economic liberal principle of free trade, and certain nation states. These are united by their class status as ruling elites and their commitment to neoliberal ideology and practice.

\section{Case Study: Brazil}

Brazil is often viewed as a significant new "agroecological country" [10] (p. 12). However, agroecology, along with agriculture more generally, has contradictory features in Brazil. On the one hand, civil society, religious organisations and farmers' movements have created a political and social movement based on food sovereignty, farmer-to-farmer knowledge sharing and autonomy of the local populations from state or corporate food production systems $[1,2,30]$. These organisations have been successful in institutionalising agroecology, with influential civil society groups including the Latin American Consortium on Agroecology (CLADES), the National Agroecology Alliance (ANA) and the Brazilian Agroecological Association (ABA-Agroecology), along with scientific institutions like the Brazilian Agricultural Research Organisation. While the ANA and ABA-Agroecology are characterised by Petersen et al. [2] as providing a countermovement to Brazil's hegemonic state-corporate neoliberal food regime, elsewhere these institutions are perceived as embodying 
a top-down, mainstream defence of agroecology in contrast with more radical, bottom-up food movements [31]. Brazil has over 100 under- and postgraduate courses in agroecology in teaching and research organisations [2], along with technical assistance and rural extension programmes which promote agroecology under the National Policy for Technical Assistance and Rural Extension (PNATER) policy of 2003. Notable recent policy developments include the National Agroecology and Organic Production Policy (PNAPO). Agroecology was also adopted by the national government in its sustainable development paradigm [32].

On the other hand, Brazil is also described as a major agribusiness power, which cultivates vast amounts of monocrops and biofuels produced for export under a state-directed, neoliberalised agri-business model [33] with huge land access and ownership inequalities [5]. Brazil's recent "agricultural miracle" [34] can be traced to recent processes of exclusion, dispossession and denial of rights produced by agricultural modernisation and green revolution policies, along with the contemporary government's focus on state-directed neoliberal governance [33]. These contradictory trends create a tension in agroecology between its agenda of social resistance to agri-food, and its growing institutionalisation in the government and other mainstream institutions.

There is a tension between whether Brazil's mainstreaming of agroecological policies and institutions provide opportunities for civil societies to further promote family farming, agroecology and food security, or whether they represent examples of greenwashing and appropriation of agroecology to maintain dominance of the current agri-food system. While Altieri and Toledo [5] view the mainstreaming of agroecology in Brazil somewhat uncritically, Petersen et al. [2] argue that the increasing institutionalisation of agroecology risks reproducing top-down interventionist approaches found elsewhere in Brazil's agricultural policy approach. This neutralises the core logic of agroecology as a social movement and it also negates agroecology's political goal of calling wider food system politics into question. Overall, the tension in Brazil's agroecology and wider agricultural development make it an important country in which to further investigate the processes of co-optation and resistance. Agriculture in Brazil is increasingly dominated by the interests of the agribusiness sector, which has exerted growing influence in macro-economic policies and in the flexibilisation of environmental and labour regulation [35]. Until 2016, there were two ministries of agriculture, one for the agribusiness sector and another, less powerful, for family farming and agrarian reform. The country is considered a main agri-food exporter, but in practice the exports are restricted to a limited list of agricultural commodities. In that context, there is very limited space for agroecological alternatives, typically considered marginal and inadequate. The expansion of agroecology in Brazil is therefore part of a wider critique of the exacerbated influence and political power of agribusiness, as much as a search for novel practices and different forms of social and economic organisation [36].

\section{Case Study: Cuba}

The case of Cuba provides a remarkable example of a quick nation-wide transition to agroecological principles. Agroecology in Cuba arose out of isolation from international agri-food systems. Cuba's food crisis of 1989, precipitated by the collapse of the Soviet Bloc, necessitated significant institutional, practical and political changes in Cuba's food system. In 1990, the state declared a special emergency period, and large state farms were broken up into small co-operatives. Virtually all farmers became members of the National Small Farmers Association of Cuba (ANAP), which was able to institutionalise openness to ecological farming and an ability to link farmers' rewards directly to their working of the land. The crisis, by which farmers could no longer access chemical or technological input, plus the leadership and communality provided by the state and the ANAP produced the pre-conditions for the widespread adoption of the Campesino-a-Campesino (CAC) methodology. Throughout the 1990s, the CAC was quickly taken up as a "revolutionary mass organisation" [14] (p. 172), and by 2000, agroecology based on the CAC methodology had spread territorially to become a national movement. 
As a consequence of this recent history, Cuba is often viewed as an example of the rapid and broad uptake of agroecology supported by state and civil-society acting in partnership, the collective management of land, and the participation and solidarity of farmers through the CAC [14,37]. Jennifer [38] and Gürcan [37] also cite the importance of agricultural markets at which locally produced food was sold locally, and Leitgeb et al. [39] report the central role that farmer-led experiments, including introducing new plant and animal species, different forms of fertilisation or experiments with mechanisation and technology, played in the success of agroecology in Cuba.

Cuba is also associated with innovations in climate change adaptation and urban food production. Rosset et al. [14] argue that the CAC methodology plus the institutionalisation of agroecology via the ANAP has resulted in greater food security despite more uncertain conditions, and greater resilience to extreme weather events. The higher survival rate of crop plants recorded on agroecological farms after Hurricane Ike in 2008 suggests agroecology can contribute to resilience. Cederlöf [40] suggests that Cuba's urban agriculture can contribute to food security, as well as linking urban agriculture with degrowth and decarbonisation agendas (the decoupling of society from neoliberal growth agendas and reliance on petro-carbon; see also [41]). Nonetheless, it must be recognised that the expansion of agroecological practices and urban agriculture in Cuba were primarily motivated by geopolitical and macroeconomic circumstances at the end of the Cold War and the collapse of the vital support coming from the USSR. In that difficult phase, called the Special Period in Time of Peace since 1989, when food and fuel were rationed, agroecology emerged as a viable and attractive alternative. The Cuban agricultural sector incorporated important agroecological solutions, with positive and emblematic results. However, there are also concrete evidences that agroecological gains may be circumstantial and there are pressures for a gradual return to conventional agriculture, which is likely to increase with the expansion of market forces that will follow the slow reconciliation with the USA. These two brief national case studies will inform the discussion in the next section on the barriers to transform the food system according to agroecological goals.

\section{Conceptual and Political Barriers to Transformation in the Food System}

The potential expansion of agroecology and its role in terms of food production do not depend only on technical productivity and efficiency gains. There are many other structural and conjectural issues that currently constrain the acceptability of agroecology by both farmers and consumers. As discussed by Frison [42], there prevails a narrow, short-term and segmented view on the agri-food system instead of an interdisciplinary scope, including within governments and organizations, which could better appreciate the contribution of agroecology. Consumers today have an expectation of cheap, easily available food that presupposes globalized markets and large-scale operations. In addition, significant investments in infrastructure and logistics have been made in order to allow the prevailing agribusiness sector to function. To a large extent, and because of business priorities, agri-food transactions are concentrated on 'cash' crops. In that sense, there is an incomplete measure of agricultural success skewing the perceived returns on different systems. Under the compelling and seductive narrative of the need to 'feed the world', power remains concentrated in a few large corporations, including supermarkets, which have strong reasons to maintain the current configuration of agri-food systems.

Against this narrow productivist argument, proponents of agroecology point out that current mainstream demands to increase food production by $70 \%$ by 2050 to meet the needs of an expanding population-the so-called "new green revolution" [43]—actually reinforce the intensification of the neoliberal agri-food hegemony, despite, it is argued, this being responsible for the food crisis in the first place [24] and ignoring the fact that $90 \%$ of farms worldwide have less than 2 hectares [44] with most food consumed domestically and locally. In that context, the concept of sustainability has been appropriated and used-in the form of sustainable intensification, for example [45] - to reinforce the power of large companies and their business allies. Along those lines, there is the risk of even co-opting agroecology and transforming it into new opportunities for capital accumulation. The reduction of agroecology to a mere 'alternative' source of profit is highly problematic and directly contradicts its 
original criticism of conventional agriculture and its roots in social and political movements, which reject the capitalist agri-food system. While sustainable intensification may be an interesting option for those farms that are already farming intensively with high external inputs, it does not conclude that this should be advocated for all producers [46].

The adoption of the concept of sustainable intensification, together with an agri-food context of the wider neoliberal political-economic systems, have led to debate about a possible 'agroecology transition'. This debate centres on how agroecology can bring about changes to the global food system to make it more socially equitable and ecologically sound. Levidow et al. [31] and Holt Giménez and Shattuck [25] identify three divergent tendencies in responses to the global neoliberal food system. The first accepts the tenets of the corporate food system described previously, but considers that minor reforms such as microcredit, agricultural aid and some local food production, along with an intensification of neoliberal measures like further market liberalisation are necessary. Ecological modernisation seeks to find ways to work from within the prevailing capitalist and carbon-based economy to bring about both ecological balance and economic development [47]. However, it is in this policy and ideological space where agroecology discourses and rhetoric can become appropriated into 'sustainable intensification' and 'climate smart agriculture' agendas. It can also become appropriated into mainstream security, resilience and sustainability discourses around multiple crises such as climate change and energy and water shortages. Increasingly, conventional agriculture is justified through the neo-Malthusian rhetoric of global crisis (see [48,49] for examples of this rhetoric, and [50] for a critique).

The second two trends are characterised as 'progressive' and 'radical' trends within global food movements more generally. The progressive trend advocates for greater sustainability in food production, for example through slow food movements, promotes agroecological techniques and local food production, and orientates towards food justice and empowerment without necessarily dismantling the agri-food system. Local scale food systems are more sustainable because they have tight feedback loops [51], which also suggests that local food systems are more resilient, as the shorter supply chains allow actors in the food system to better respond to and adaptively manage disruptions, shocks and other system signals.

The radical trend orientates towards food sovereignty and a radical overthrow of the agri-food regime based on land redistribution, rights-based approaches to water and seeds, and a widespread transition to an agroecological paradigm (see [25], pp. 117-118). The reformist and radical trends are portrayed as sharing much common ground. However, the latter is distinguished by its calls for complete regime change. Either of these approaches, depending on whether or not they are accompanied by regime change, could be seen as movement towards an eco-economy, which Kitchen and Marsden [52] (p. 758) define as "an alternative and diverse arena for the development of new production and consumption chains and networks. It consists of complex networks or webs of viable businesses and economic activities that utilise the varied and differentiated forms of ecological resources in more sustainable and ecologically efficient ways. Importantly, these do not result in a net depletion of resources, but instead provide cumulative net benefits that add value to rural and regional spaces in both ecological and economic ways".

There is some debate around the conditions under which change could be brought about. Holt-Giménez and Shattuck [25] frame the possibilities for transformation in terms of Polyani's double movement. This analysis considers that capitalism produces a dialectical relationship between increasing liberalisation and reform in the form of social protection. Consequently, reformist initiatives, while they may make the dominant food regime less damaging in the short term or in some limited areas, ultimately fail to alter overall power structures. In some cases, they may even add to the overall strength of the system by providing legitimacy to certain actors and enabling the debate to be deflected from underlying political aspects of food regimes. Consequently, progressive agendas are easily co-opted into mainstream reformist discourses under the claim that all solutions are necessary to avert food (and other) crises. In contrast, the radical movement, characterised by groups such as La Via Campesina (https://www.viacampesina.org/en/) or even IFOAM (International Foundation 
for Organic Agriculture), adopt a much more explicitly political platform based on land reform, democratic ownership of food production and the strong regulation of markets such as guaranteed pricing and farmer control over seeds.

The relationship between the two agendas is discussed by Levidow et al. [31]. The importance of social movements is a shared concern between progressive and radical agendas. Indeed, both Levidow et al. [31] and Holt Giménez and Shattuck [25] consider that strategic alliances between progressive and radical social movements are key to bringing about wider change, provided progressive projects and ideas are not co-opted into mainstream reformist agendas. However, there are also multiple tensions between and within these broad-brush agendas that deserve further attention. For example, class complexities are identified by Holt Giménez and Shattuck [25], as middle-class critiques of industrial food production such as the slow food movement both intersect with, and are in tension with more explicitly class-based food critiques such as the Detroit Black Community Food Security Network. Similarly, race, gender and other identity politics deserve further analysis in terms of how particular movements position themselves in the broader progressive-reformist analytic. In short, Levidow et al. [31] caution that transformation is contingent on particular contexts and groups of actors, which can only be discerned empirically, and to beware of the use of agroecology as a 'buzzword' for transition.

The question of whether change happens through gradual reform or through radical revolution is therefore an ongoing conceptual and empirical one, and there are major questions and gaps specific to agroecology. These include the conceptual and practical implications of adopting a food sovereignty approach (allowing communities a control over the way food is produced, traded and consumed), the links between accumulation by dispossession and expanded capitalist reproduction of food systems, and the implications to political agroecology of adopting a food systems approach. These questions have been introduced yet not fully explored in the current research agenda. Moreover, the nature of the links between agroecology and wider food regime discourses have only been substantively discussed in the two papers mentioned here, while the use of agroecology ideas in relation to wider crisis discourses does not appear to have been analytically addressed at all.

\section{Challenges Facing Agroecology: Productivity and the Yield Gap}

There are a number of physical, logistical and ecological challenges to overcome in order to promote greater expansion of agroecological systems. A general trend of land abandonment and migration of rural populations into urban areas, and a reverse trend of immigrant labour moving into these rural areas to take up the manual agricultural labour, has led to a combination of land abandonment, concentration of land into larger holdings and a shift from extensive to intensive agricultural practices [53]. These dynamics lead to a limited number of landowners and labour to manage labour-and knowledge-intensive agroecological farming systems.

In addition to this, and despite research on the subject, questions remain about whether or not a yield gap exists between conventional and agroecological production systems. The apparently lower productivity of agroecological systems is commonly used by mainstream farmers, corporations and policy-makers to justify their disregard for alternative practices and associated transformations. Research results vary depending on the type of information considered and the methodologies applied, but there are emerging data that point to comparable yields and higher yield stability under extreme weather conditions [14], as well as improved profitability owing to increased prices received for products and reduced input costs.

The global survey of organic farming by Badgeley et al. [54] is frequently cited in agroecology research, as it concluded that organic methods could replace intensive and input-heavy conventional farming, while maintaining, and even increasing food supply, on the same land base. The study is evidently encouraging for agroecologists as it states that "many organic farmers use polycultures and multiple cropping systems, from which the total production per unit area is often substantially higher than for single crops" [54] (p. 94). However, while the study is used to support claims that agroecology 
can increase food production (e.g., [14], p. 177), the research does not focus on agroecology directly, undermining the practical application of its findings.

Rosset et al. [14] (p. 164) claim that "in the South peasant agroecological systems average a higher level of total productivity than conventional monocultures". This is based on data from Cuba that indicates a nearly three-fold increase in total productivity from the peasant sector between 1998 and 2009. This increase in output coincides with the widespread rollout of agroecological methods across Cuba in the same period. On the basis of this evidence, Rosset et al. [14] claim that the greater the extent of agroecological methods adopted on a farm, the greater the productivity. However, the study notes that proving cause and effect is difficult.

On the other hand, there is an interesting debate over whether productivity is the most important measurement for evaluating agroecology. While claiming greater productivity is attractive to agroecologists, Altieri [55] argues that all-round food security is more important than single-species productivity (which is the typical configuration of conventional, intensive agriculture). His 2000 study focused directly on productivity in Latin American agroecological farming, claiming that peasant farming makes a substantial contribution to food security in the region despite poor conditions and low use of inputs. While the study concedes that peasant farming does not often produce marketable surpluses of single crops, the reasons given for this are related to a lack of market opportunities rather than a deficiency in agroecological principles. Given increasing extreme weather events, including prolonged droughts and flooding, resilience of the production system is of growing importance. This conclusion deserves even more attention in a context of anthropogenic climate change, which is not only a cause of higher bio-climatological risks but is, to a significant extent, connected with deforestation and the use of fossil fuels by mainstream agriculture.

The assessment of agroecology's productivity is often affected by the use of somewhat out-of-date data, indicating a lack of recent and consistent evaluations in this area [56]. Altieri and Toledo cite evidence from Brazil that showed that polyculture mixes of maize and beans produced $28 \%$ more food than similar monocultures of the same crop [57]. Studies from the Amazon claimed a 200 percent advantage in agroecological yields over colonial-style monoculture [58]. And research from Guatemala indicated a much greater efficiency of maize farming using agroecology principles [59] (all cited in [5], p. 596). They also cite studies from Mexico that claimed that a 1 hectare plot of land under agroecological management produced as much food as a 1.73 hectare plot planted with maize monoculture [5] (p. 595). Using this research, they claim that "in polycultures developed by smallholders productivity in terms of harvestable products per unit area is higher than under sole cropping with the same level of management" [5] (p. 595). However, there are no original references provided for the Mexico studies, and several of the other background studies are now dated, indicating a lack of up-to-date research, which is likely related to the hegemonic influence of agribusiness in the region.

One has only to look at statistics about spending on research and development in agroecological systems versus conventional production systems to see the hegemonic control of agribusinesses. For instance, in the European Union about $80 \%$ of subsidies and $90 \%$ of research funding go to support conventional industrial agriculture [60]. Consider that in light of the mixed results comparing yield data from conventional and agroecological systems. If the same amount of money was spent on agroecological research, then knowledge exchange to promote innovation in production practices would no longer be an obstacle to further improving system performance [45] and more research could be established under consistent methodologies to measure productivity and sustainability (more on this to follow in the next section).

In response to these challenges, there are also at least three debates around how to gather and present data. The first centres on whether total output should be considered, rather than single-crop yield. Agroecology supporters argue that a multi-crop, multi-species agroecological farm with a diverse range of products over multiple seasons could not compete on a crop-by-crop basis with a single output industrial farm $[5,55]$. A second difficulty is the patchy and uneven application of agroecological 
principles. It is not unusual for farmers to selectively adopt agroecological principles as part of an uneven and graduated journey to 'full' agroecological sustainability, so it can be difficult to isolate which practice produces productivity gains [5]. Furthermore, agroecological practices are place-based and thus the composition of practices used will be different from one context to the next. The third question has to do with how to measure input and output, e.g., how to incorporate labour inputs, and how to include food produced for subsistence, which is not counted as a marketable output (and so is not captured in some data records; [14]). Bernstein [56] calls for greater attention to the issue of labour intensity and food security when assessing the output of agroecology, which will have very different implications in developed and developing country contexts. Overall, data seem to be mixed, and the literature would benefit from a clear methodology on how to gather and compare information on productivity, along with more comprehensive and up-to-date studies.

\section{Further Research and Knowledge Gaps}

Much of the existing evidence on environmental sustainability of agriculture focuses on individual outcomes or aspects of land management: the challenge is to integrate this information to inform a sustainable approach to system and landscape management. Furthermore, the true environmental, social and health costs of different agricultural production systems also need to be better understood. For instance, whether increased biodiversity in agroecological systems contributes to overall conservation efforts $[61,62]$ or how different farming systems enhance social capacity and community engagement, and how this contributes to social components of sustainability. To this end, the role and nature of knowledge in agroecology should be further explored, particularly around how to generate creative, democratic and transformative research projects, and concerning the heterogeneous and context-specific nature of claims to transformative participatory knowledge.

Gliessman [63] (p. 5) suggested a general principle that "the greater the structural and functional similarity of an agro-ecosystem to the natural ecosystems in its biogeographic region, the greater the likelihood that the agro-ecosystem will be sustainable". This has often been reproduced in ideas that agroecology will help restore sustainability, such as "the transition to sustainability" in Mendez et al. [7], along with Altieri [55]. Although ecological sustainability is often invoked, it is underexplored, and literature that critiques the concept is seldom incorporated. Agroecology literature would benefit from more theorising around an agroecological perspective on what 'sustainability' actually means (although it should be noted that sustainability is a slippery and highly contested concept). Understanding the environmental, social and health costs and benefits will contribute to the development of defined metrics for comprehensively evaluating the sustainability of agricultural systems, which are still lacking, but would make significant contributions to business and policy decisions [45], as well as regulatory approaches that impose minimum environmental standards and stimulate good practice. One such approach to this is the Social Return on Investment analysis (SROI), defined as "a holistic cost-benefit analysis, the methodology evaluates activities across the 'triple bottom line' of social, environmental and economic impacts, taking into account what is valued by representatives of local constituencies and deemed relevant to the assessment" [64]. Whichever approach chosen, agroecology will benefit greatly from a standardized methodological approach.

While the literature still lacks methods for quantifying the value of and costs of maintaining ecosystem services [65], tools to assess the trade-offs between delivering different ecosystem services within different agricultural systems [66], and measures that might be adopted to deliver more effective means of marketizing ecosystem services and rewarding land managers for their delivery [66], the research in these areas is moving quickly to fill these gaps [67].

Finally, and importantly, the role of the state is severely under-analysed in the transformation debate and in relation to the promotion of agroecological practices. While Pahnke [33], Rosset et al. [14] and Holt Giménez [68] demonstrate the important role of the Brazilian, Cuban and other Latin American states in institutionalising and mainstreaming agroecology and supporting social movements, this has not been taken further to consider the role of the state in shoring up dominant 
food regimes and how the state can bring about a transition. Instead of a monolithic entity above social and ecological controversies, the state needs to be seen as a socio-political relation that is susceptible to different pressures and whose responses reflect ideologies and the balance of power. Empirical questions include determining the relationship between agri-food corporations and particular states. This then relates to wider and ongoing questions over the role of the state in the expansion and entrenchment of neoliberalisation that take place in disciplines like political geography, development studies and international relations.

In examining the role of the state, it is important to question the role of current and historic institutional frameworks in nurturing or otherwise, place-based agricultural initiatives [47] as well as the role of the state in creating economic incentives to make agroecology a more profitable choice for producers. The incremental 'successes' in transforming conventional farming systems towards more sustainable agroecological production (the use of the term 'success' in some of the below examples is arguable, but it could be seen as such with regards to shifting paradigms) could be inspired by the French agroecology action plan, the Scottish organic agriculture action plan or by Switzerland's 'multifunctional farmland' approach (adopted after the 1996 referendum) as examples of how the state can play a role in prioritizing agroecology, and the economic benefits of ecosystem services [69].

More generally, political agroecology literature, particularly that which advocates family and community work and local livelihood diversification strategies [16], as well as localised food provision and local markets [17] appears to have a tendency to under-theorise and idealise the community. Agroecology may therefore benefit from applying a more critical perspective to the community, for example by conducting case-based research which makes issues like gender and community-level power relations explicit. It is quite relevant that, as suggested by Bernstein, agroecology literature often under-analyses the category of peasant, farm labourer, small-scale farmer and medium-scale farmer, failing to clearly differentiate between these classes. In particular, the category of farm labourer receives scant attention. The claims made by proponents of small-scale and agroecological farming to promote food sovereignty on the basis of an idealised community need greater examination in terms of specific farming groups, and the relationships between and among this heterogeneous group.

Turning to questions of epistemology, there has been substantive consideration of whether agroecology is a science [1], with Dalgaard et al. [9] concluding that the principles of scientific agroecology adhere to Western scientific epistemologies, norms and methodologies. As previously discussed, several agroecologists consider that science is moving beyond disciplinary silos, and agroecology represents a dynamic opportunity for genuine transdisciplinary innovation and the opportunity to embrace imperfection and uncertainty in knowledge claims [12]. However, questions remain over how political agroecology knowledge could be integrated into policy knowledge (i.e., is critical/political social science relevant to policy makers who tend to prefer generalizable, quantifiable knowledge which indicates technical solutions). This epistemological debate relates to how (and whether) to institutionalise agroecology, how to spread and mobilise its ideas, how (and whether) to develop knowledge that is relevant to policy-makers, and whether the claims of agroecology which take into account the so-called 'human dimensions' can be seen as disinterested scientific knowledge (and whether/ how this matters).

There are also questions around how scientific knowledge could be politicised and democratised in a way that facilitates the advance of agroecology. Considering the prevailing trends and neoliberalising context of present-day universities and research centres, it is difficult to expect any sudden enthusiasm for agroecology-related politics. Levidow et al. [31] argue that scientific agroecology research needs to be politicised, with researchers actively considering the transformative potential of the knowledge they produce through their research. This may include changes to academic funding to democratise and broaden research, greater support for bottom up research, changing teaching and other forms of research dissemination, and through innovative research agendas such as participatory plant breeding and promoting shorter food chains [31]. 
Finally, an important research gap appears to be animal agroecology, i.e., a focus on applying agroecological principles to animal husbandry and meat production and consumption. Increasing meat consumption is a major cause of climate change, particularly given the increase of meat consumption among middle classes in developing countries. Industrial meat production raises ethical and environmental questions [70], and consequently could benefit from the application of agroecological principles [71]. A further perspective might be a more-than-human ethical and theoretical approach. Current agroecology literature does not appear to have considered animals as moral beings (for example, how might an agroecological approach contribute to animal welfare?), nor has it considered literature that analyses the role of non-human animals as agents in technical-agricultural processes (e.g., [72]).

\section{Conclusions}

This article demonstrates that agroecology is a young field of environmental, social and politico-economic activity with evolving definitions and debates. From its roots as a branch of agricultural science, agroecology has developed into a transdisciplinary field in which political and social questions are currently front and centre. Latin American agroecologists in particular have focused on questions of democratisation and transformation of food production and consumption, advocating sustainable farm practices based on the farm's own ecology rather than external inputs, alongside participatory, farmer-led knowledge, and the ways in which food production can be made more local and in tune with traditional, sustainable livelihoods. Agroecology has been conceptualised as a farmer-led countermovement against the modern agri-food system based on the holistic practices of agroecological food production (local, participatory and action-orientated) alongside the principles of sustainability and autonomy in food production.

Recently, agroecology's social perspective has become more overtly politicised, with a focus on critiquing and challenging broader food systems, especially the conventional agri-food system dominated by large corporations, market ideologies and governments. Contemporary debates increasingly focus on the transformation of food regimes and food systems, and often invoke notions of food sovereignty. This allows agroecologists to distinguish between reformist, progressive and radical tendencies in food movements, and to begin theorising the appropriation of agroecology into mainstream neoliberal discourses of multiple crises (water, climate, biodiversity). However, much in this debate remains implicit and taken for granted. This brief discussion has identified particular gaps including issues around defining sustainability and metrics for measuring this, scaling up, the relationship between normative and ideological calls for food sovereignty and the realities of farmer's experiences, an idealisation of the peasant farmer against monolithic and simplistic characterizations of food regimes, ongoing questions about the productivity of agroecology, and a lack of analysis of the role of the state.

A final conclusion is that the transformative role for agroecology depends on integrating its three forms in practice-transdisciplinary knowledges, interdisciplinary agricultural practices and social movements [31]. In that sense, the way forward in the transformation of the food systems according to the goals of sustainability, justice and sovereignty will require responsible action to improve access to food and nutrition of a constantly growing global population. At the same time, a focus on agroecology should recognize the invaluable role played by farmers and the need to conserve the natural capital resource base upon which the system, and the broader society, depends.

Acknowledgments: The authors completed this review with support from ESRC Nexus Networks: 'Agroecological Business: Connecting civil society, SMEs and consumers to nature and the land'. The authors also want to express their gratitude to two knowledgeable and supportive anonymous referees.

Author Contributions: Angelina Sanderson Bellamy and Antonio A. R. Ioris conceived and designed the paper jointly; Angelina Sanderson Bellamy and Antonio A. R. Ioris both wrote sections of the paper and then worked collaboratively to merge the sections of the paper and edit it for publication. Angelina Sanderson Bellamy prepared the manuscript for submission. 
Conflicts of Interest: The authors declare no conflict of interest.

\section{References}

1. Wezel, A.; Bellon, S.; Doré, T.; Francis, C.; Vallod, D.; David, C. Agroecology as a science, a movement and a practice. Sustain. Agric. 2011, 2, 27-43.

2. Petersen, P.; Mussoi, E.M.; Dal Soglio, F. Institutionalization of the agroecological approach in Brazil: Advances and challenges. Agroecol. Sustain. Food Syst. 2013, 37, 103-114. [CrossRef]

3. Gliessman, S. Transforming food systems to sustainability with agroecology. J. Sustain. Agric. 2011, 35, 823-825. [CrossRef]

4. Gliessman, S. Agroecology: Growing the roots of resistance. Agroecol. Sustain. Food Syst. 2013, 37, $19-31$.

5. Altieri, M.A.; Toledo, V.M. The agroecological revolution in Latin America: Rescuing nature, ensuring food sovereignty and empowering peasants. J. Peasant Stud. 2011, 38, 587-612. [CrossRef]

6. Freibauer, A.; Mathijs, E.; Brunori, G.; Damianova, Z.; Faroult, E.; Girona, J.; Gomis, I.; O’Brien, L.; Treyer, S. Sustainable Food Consumption and Production in a Resource-Constrained World; The 3rd SCAR Foresight Exercise; European Commission: Brussels, Belgium, 2011.

7. Méndez, V.E.; Bacon, C.M.; Cohen, R. Agroecology as a transdisciplinary, participatory, and action-oriented approach. Agroecol. Sustain. Food Syst. 2013, 37, 3-18.

8. Gonzalez de Molina, M. Agroecology and politics. How to get sustainability? About the necessity for a political agroecology. Agroecol. Sustain. Food Syst. 2013, 37, 45-59.

9. Dalgaard, T.; Hutchings, N.J.; Porter, J.R. Agroecology, scaling and interdisciplinarity. Agri. Ecosyst. Environ. 2003, 100, 39-51. [CrossRef]

10. Wezel, A.; Soldat, V. A quantitative and qualitative historical analysis of the scientific discipline of agroecology. Int. J. Agric. Sustain. 2009, 7, 3-18. [CrossRef]

11. Francis, C.; Lieblein, G.; Gliessman, S.; Breland, T.A.; Creamer, N.; Harwood, R.; Salomonsson, L.; Helenius, J.; Rickerl, D.; Salvador, R.; et al. Agroecology: The Ecology of Food Systems. J. Sustain. Agric. 2003, 22, 99-118. [CrossRef]

12. Vandermeer, J.; Perfecto, I. Complex traditions: Intersecting theoretical frameworks in agroecological research. Agroecol. Sustain. Food Syst. 2013, 37, 76-89. [CrossRef]

13. Chambers, R. Rural Development: Putting the Last First; Longmans: Essex, UK; John Wiley: New York, NY, USA, 1983.

14. Rosset, P.M.; Machin Sosa, B.; Roque Jaime, A.M.; Ávila Lozano, D.R. The Campesino-to-Campesino agroecology movement of ANAP in Cuba: Social process methodology in the construction of sustainable peasant agriculture and food sovereignty. J. Peasant Stud. 2011, 38, 161-191. [CrossRef] [PubMed]

15. Garnier, E.; Navas, M.-L. A trait-based approach to comparative functional plant ecology: Concepts, methods and applications for agroecology. A review. Agron. Sustain. Dev. 2012, 32, 365-399. [CrossRef]

16. Schneider, S.; Niederle, P.A. Resistance strategies and diversification of rural livelihoods: The construction of autonomy among Brazilian family farmers. J. Peasant Stud. 2010, 37, 379-405. [CrossRef]

17. Martínez-Torres, M.E.; Rosset, P.M. Diálogo de saberes in La Vía Campesina: Food sovereignty and agroecology. J. Peasant Stud. 2014, 41, 979-997. [CrossRef]

18. Gliessman, S.R. Agroecology: The Ecology of Sustainable Food Systems; CRC Press: New York, NY, USA; Taylor \& Francis: New York, NY, USA, 2007.

19. Chambers, R. Whose Reality Counts? Putting the First Last; Intermediate Technology Publications Ltd. (ITP): London, UK, 1997.

20. Uphoff, N. (Ed.) Agroecological Innovations: Increasing Food Production with Participatory Development; Earthscan Publications: London, UK, 2013.

21. Warner, K. Agroecology in Action: Extending Alternative Agriculture through Social Networks; MIT Press: Cambridge, MA, USA, 2007.

22. Sevilla Guzmán, E.; Woodgate, G. Agroecology: Foundations in agrarian social thought and sociological theory. Agroecol. Sustain. Food Syst. 2013, 37, 32-44.

23. Peet, R.; Watts, M. Liberation Ecologies: Environment, Development, Social Movements; Routledge: New York, NY, USA, 2004; Volume 2, pp. 3-43. 
24. Holt-Giménez, E.; Altieri, M.A. Agroecology, food sovereignty, and the new green revolution. Agroecol. Sustain. Food Syst. 2013, 37, 90-102.

25. Holt-Giménez, E.; Shattuck, A. Food crises, food regimes and food movements: Rumblings of reform or tides of transformation? J. Peasant Stud. 2011, 38, 109-144. [CrossRef] [PubMed]

26. Shiva, V. Soil Not Oil: Climate Change, Peak Oil and Food Insecurity; Zed Books: London, UK, 2008.

27. Guzmán, G.I.; González de Molina, M.; Alonso, A.M. The land cost of agrarian sustainability. An assessment. Land Use Policy 2011, 28, 825-835. [CrossRef]

28. McMichael, P. A food regime genealogy. J. Peasant Stud. 2009, 36, 139-169. [CrossRef]

29. Friedmann, H. The political economy of food: A global crisis. New Left Rev. 1993, 197, $29-57$.

30. Botelho, M.I.V.; Cardoso, I.M.; Otsuki, K. “I Made a Pact with God, with Nature, and with Myself”: Exploring Deep Agroecology. Agroecol. Sustain. Food Syst. 2016, 40, 116-131. [CrossRef]

31. Levidow, L.; Pimbert, M.; Vanloqueren, G. Agroecological research: Conforming-Or transforming the dominant agro-food regime? Agroecol. Sustain. Food Syst. 2014, 38, 1127-1155. [CrossRef]

32. Ministry of Agrarian Development of Brazil. Plano Nacional de Agroecologia e Produção Orgânica. 2013. Available online: http://www.mda.gov.br/portalmda/sites/default/files/ceazinepdf/cartilha-lt_PLANO_ NACIONAL_DE_AGR-379811.pdf (accessed on 13 January 2016). (In Portuguese)

33. Pahnke, A. Institutionalizing economies of opposition: Explaining and evaluating the success of the MST's cooperatives and agroecological repeasantization. J. Peasant Stud. 2015, 42, 1087-1107. [CrossRef]

34. Economist: Brazil's Agricultural Miracle; How to Feed the World-the Emerging Conventional Wisdom about World Farming Is Gloomy; There Is an Alternative. The Economist, 2010. Available online: http://www. economist.com/node/16889019 (accessed on 22 February 2017).

35. Ioris, A.A.R. Encroachment and entrenchment of agro-neoliberalism in the Centre-West of Brazil. J. Rural Stud. 2017, 51, 15-27. [CrossRef]

36. Ioris, A.A.R. Rent of agribusiness in the Amazon: A case study from Mato Grosso. Land Use Policy 2016, 59, 456-466. [CrossRef]

37. Gürcan, E.C. Cuban Agriculture and Food Sovereignty beyond Civil-Society-Centric and Globalist Paradigms. Lat. Am. Perspect. 2014, 41, 129-146. [CrossRef]

38. Jennifer, A. The role of the 1990s food markets in the decentralization of Cuban agriculture. Cuba. Stud. 1998, 27, 21-39.

39. Leitgeb, F.; Kummer, S.; Funes-Monzote, F.R.; Vogl, C.R. Farmers' experiments in Cuba. Renew. Agric. Food Syst. 2014, 29, 48-64. [CrossRef]

40. Cederlöf, G. Low-carbon food supply: The ecological geography of Cuban urban agriculture and agroecological theory. Agric. Hum. Values 2016, 33, 771-784. [CrossRef]

41. Buchmann, C. Cuban home gardens and their role in social-ecological resilience. Hum. Ecol. 2009, 37, 705-721. [CrossRef]

42. Frison, E. Let's Put an End to the "Feed the World" Narrative. CGIAR Research Program on Water, Land and Ecosystems Blog Post. 2016. Available online: https://wle.cgiar.org/thrive/2016/04/17/let\%E2\%80\% 99s-put-end-\%E2\%80\%9Cfeed-world $\%$ E2\%80\%9D\%C2\%A0narrative (accessed on 11 January 2017).

43. De Schutter, O.; Vanloqueren, G. The new green revolution: How twenty-first-century science can feed the world. Solutions 2011, 2, 33-44.

44. IAASTD. IAASTD Global Report: Summary for Decision Makers; Island Press: Washington DC, USA, 2009.

45. Lampkin, N.H.; Pearce, B.D.; Leake, A.R.; Creissen, H.; Gerrard, C.L.; Girling, R.; Lloyd, S.; Padel, S.; Smith, J.; Smith, L.G.; et al. The Role of Agroecology in Sustainable Intensification. Report for the Land Use Policy Group; Organic Research Centre, Elm Farm: Newbury, UK; Game \& Wildlife Conservation Trust: Fordingbridge, UK, 2015.

46. Elliott, J.; Firbank, L.G.; Drake, B.; Cao, Y.; Gooday, R. Exploring the Concept of Sustainable Intensification; UK Nature Conservation Agencies Land Use Policy Group: London, UK, 2013.

47. Horlings, L.G.; Marsden, T.K. Towards the real green revolution? Exploring the conceptual dimensions of a new ecological modernisation of agriculture that could 'feed the world'. Glob. Environ. Chang. 2011, 21, 441-452. [CrossRef] 
48. World Bank. Agriculture for Development, 2008. World Development Report. 2008. Available online: http: //siteresources.worldbank.org/INTWDR2008/Resources/WDR_00_book.pdf (accessed on 11 January 2017).

49. Royal Society. Reaping the Benefits: Science and the Sustainable Intensification of Global Agriculture; Royal Society: London, UK, 2009.

50. La Via Campesina. Sustainable Peasant and Family Farm Agriculture Can Feed the World; Via Campesina: Jakarta, Indonesia, 2010.

51. Sundkvist, A.; Milestad, R.; Jansson, A. On the importance of tightening feedback loops for sustainable development of food systems. Food Policy 2005, 30, 224-239. [CrossRef]

52. Kitchen, L.; Marsden, T. Creating Sustainable Rural Development through Stimulating the Eco-economy: Beyond the Eco-economic Paradox? Sociol. Rural. 2009, 49, 273-294. [CrossRef]

53. Labrianidis, L.; Sykas, T. Migrants, economic mobility and socio-economic change in rural areas: The case of Greece. Eur. Urban Reg. Stud. 2009, 16, 237-256. [CrossRef]

54. Badgley, C.; Moghtader, J.; Quintero, E.; Zakem, E.; Chappell, M.J.; Aviles-Vazquez, K.; Samulon, A.; Perfecto, I. Organic agriculture and the global food supply. Renew. Agric. Food Syst. 2007, 22, 86-108. [CrossRef]

55. Altieri, M.A. Multifunctional dimensions of ecologically-based agriculture in Latin America. Int. J. Sustain. Dev. World Ecol. 2000, 7, 62-75. [CrossRef]

56. Bernstein, H. Food sovereignty via the 'peasant way': A sceptical view. J. Peasant Stud. 2014, 41, 1031-1063. [CrossRef]

57. Francis, C.A. Multiple Cropping Systems; MacMillan: New York, NY, USA, 1986.

58. Hecht, S.B. The sacred cow in the green hell: Livestock and forest conversion in the Brazilian Amazon. Ecologist 1989, 19, 229-234.

59. Pimentel, D.; Pimentel, M. Food, Energy and Society; Edward Arnold: London, UK, 1979.

60. UN: Only Small Farmers and Agroecology can Feed the World. Available online: http://www.theecologist. org/News/news_analysis/2566719/un_only_small_farmers_and_agroecology_can_feed_the_world.html (accessed on 15 January 2016).

61. Birkhofer, K.; Ekroos, J.; Corlett, E.B.; Smith, H.G. Winners and losers of organic cereal farming in animal communities across Central and Northern Europe. Biol. Conserv. 2014, 175, 25-33. [CrossRef]

62. Tuck, S.L.; Winqvist, C.; Mota, F.; Ahnstrom, J.; Turnbull, L.A.; Bengtsson, J. Land-use intensity and the effects of organic farming on biodiversity: A hierarchical meta-analysis. J. Appl. Ecol. 2014, 51, 746-755. [CrossRef] [PubMed]

63. Gliessman, S.R. Agroecology and sustainability. In Proceedings of the INTECOL Symposium, Florence, Italy, 19-25 July 1998; Volume 8, pp. 1-9.

64. NEF (New Economics Foundation). The Benefits of Procuring School Meals through the Food For Life Partnership: An Economic Analysis; New Economics Foundation: London, UK, 2011.

65. Andres, C.; Bhullar, G.S. Sustainable Intensification of Tropical Agro-Ecosystems: Need and Potentials. Front. Environ. Sci. 2016, 4, 5. [CrossRef]

66. Dicks, L.V.; Bardgett, R.D.; Bell, J.; Benton, T.G.; Booth, A.; Bouwman, J.; Brown, C.; Bruce, A.; Burgess, P.J.; Butler, S.J.; et al. What do we need to know to enhance the environmental sustainability of agricultural production? A prioritisation of knowledge needs for the UK food system. Sustainability 2013, 5, 3095-3115. [CrossRef]

67. Kareiva, P.; Tallis, H.; Ricketts, T.H.; Daily, G.C.; Polasky, S. (Eds.) Natural Capital: Theory and Practice of Mapping Ecosystem Services; Oxford University Press: Oxford, UK, 2011.

68. Holt-Giménez, E. Campesino a Campesino: Voices from Latin America's Farmer to Farmer Movement for Sustainable Agriculture; Food first books: Oakland, CA, USA, 2006.

69. Baumgartner, N.A.; Marder, H.P.; Munzinger, J.; Siegrist, H.H. Frequency of Cryptosporidium sas cause of human gastrointestinal disease in Switzerland and possible sources of infection. Schweiz. Med. Wochenschr. 2000, 130, 1252-1258. [PubMed]

70. Nijdam, D.; Rood, T.; Westhoek, H. The price of protein: Review of land use and carbon footprints from life cycle assessments of animal food products and their substitutes. Food Policy 2012, 37, 760-770. [CrossRef] 
71. Dumont, B.; González-García, E.; Thomas, M.; Fortun-Lamothe, L.; Ducrot, C.; Dourmad, J.Y.; Tichit, M. Forty research issues for the redesign of animal production systems in the 21st century. Agroecol. Integr. Anim. Agroecosyst. 2014, 8, 1382-1393. [CrossRef] [PubMed]

72. Holloway, L.; Bear, C.; Wilkinson, K. Re-capturing bovine life: Robot-cow relationships, freedom and control in dairy farming. J. Rural Stud. 2014, 33, 131-140. [CrossRef] 